\title{
Frequency of Major Depressive Disorders Among Obese Adults Patients Attending to Academic Port-Fouad Family Practice Center Faculty of Medicine, Suez Canal University
}

\author{
Samar A. Elalfy ${ }^{*}$ Doaa E. Karama, Nahed A. Eldahshan \\ Department of Family Medicine, Faculty of Medicine, Suez Canal University, Egypt
}

\begin{abstract}
Background: Obesity has become a major contributor to the global burden of chronic disease and disability. Studies have consistently found a modest association between depression and obesity. Meta-analysis of 17 community-based studies found that obese people were 1.18 times more likely to have depressive symptoms than those who were not obese. This relationship has been suggested to be dose dependent, with a higher body mass index (BMI) being linked to a greater likelihood of clinical depression. Aim: to estimate the frequency of major depressive disorders among obese adults patients. Patients and Methods: The present study was designed as descriptive analytical cross-sectional study that included 129 adult obese patients attending to Academic Port-Fouad Family Practice Center, Faculty of Medicine, Suez Canal University. Results: Mean age of the patients in different groups was comparable $(p=0.52) ., 53.5 \%$ of obese patients in our sample had no depression, whereas $41.9 \%$ had mild depressive symptoms and $4.7 \%$ are severely depressed. Frequency of eating dairy products was significantly different between depressed and non-depressed patients $(p=0.027)$. Depressed patients significantly had a greater number of snakes ( $2.25 \pm 1.83$ times) than those with no depression $(p=0.011)$. Depressed patients were significantly less satisfied with their body shape $(p=0.008)$. Conclusion: Depression often accompanies obesity. Therefore, it is recommended that health professionals should always explore the presence of depression and suicidality in obese patients.
\end{abstract}

Keywords: Major depression disorder, Obesity, and Prevalence.

\section{Introduction}

Obesity is a chronic disease of individual and public health which affects many people all over the world. Obesity has become a major contributor to the global burden of chronic disease and disability. It is a complex condition with serious social and psychological dimensions, affecting virtually all ages and socioeconomic groups ${ }^{(1)}$. The most used definitions of obesity are based on BMI, which is defined as weight in kilograms divided by height in meters squared. In adults, obesity is generally defined as a BMI of 30.0 or greater ${ }^{(2)}$. Recent epidemiological studies show that a high percentage of people have some kind of pathology associated with obesity, reaching figures exceeding 300 million all over the world(3). As prevalence rate of obesity in adults $32 \%$ in 
Egypt (who 2016), in the Eastern Mediterranean Region, some research studies confirmed that overweight has reached an alarming level. During adulthood, women showed a higher prevalence of obesity (35-75\%) compared with men (30-60\%) ${ }^{(4)}$. In an Egyptian study, the prevalence of obesity among adults was 24.1 and $28.7 \%$ based on the waist circumference and waist-to-hip ratio indicators, respectively(5). Depression and obesity are common, with an estimated 350 million and 500 million people globally with these respective conditions ${ }^{(6)}$. Studies have consistently found a modest association between depression and obesity. Meta-analysis of 17 community-based studies found that obese people were 1, 18 times more likely to have depressive symptoms than those who were not obese, with this association more clearly present among women than men. Evidence of a relationship between depression and obesity was found in a meta-analysis of Iongitudinal studies$^{(7)}$. Obesity increased the odds of subsequent depression by 1,27 and 1, 55 respectively, while depression increased the odds of obesity at follow-up by 1,58 . This relationship has been suggested to be dose dependent, with a higher body mass index (BMI) being linked to a greater likelihood of clinical depression ${ }^{(8)}$. Another study administered at Ain Shams University, which followed 50 obese adults for one year, found that females with depression were 54 percent more likely to be affected by obesity at the end of the study than those who were not obese; no such association was found in males ${ }^{(9)}$. In many countries, including Australia, the UK, and Canada, clinical practice guidelines recommend that family physicians play a role in the management of both obesity and depression ${ }^{(10)}$. Recent data from Australia's Bettering the Evaluation and Care of Health (BEACH) study of family physicians found that depression was the fifth most frequently managed problem, and weight and nutrition counseling was the most common preventative treatment administered. The frequency with which these conditions are encountered in primary care suggests that family physicians may need to be equipped to provide comprehensive care to patients with depression and obesity ${ }^{(11)}$. The National Health and Nutrition Examination Survey data showed that among the most obese adults, in the 95th to 10oth percentile, the prevalence of major depression increased to highly significant levels, $20 \%$ for men and 30\% for women $^{(12)}$. An analysis of previous studies looking at depression and obesity (BMI more than 30) published in the Archives of General Psychiatry in 2010 re-confirmed the link between the two and showed that being affected by obesity at the start of the studies significantly increased the chance of having depression later among people more than 20 years old, but not for teens or children. And, having depression at the start significantly increased the chances of developing obesity later ${ }^{(13)}$. There is no enough data base for the association between obesity and depression in Egypt and also the prevalence of depression in obese adults which needs further studies. so this research will be carried out to estimate the prevalence of depression among adults with obesity in port Fouad city. This study was con-ducted to improve the quality of life of obese patients attending to Academic Port-Fouad Family Practice Center, Faculty of Medicine, Suez Canal University.

\section{Subjects and Methods}

This work is a descriptive cross sectional analytical study was carried out in Academic Port-Fouad Family Practice Center, Faculty of Medicine, Suez Canal University. Adults who were diagnosed with obesity 
to evaluate the prevalence of major depressive disorders in these patients through a simple concise and informative questionnaire. Our study included 129 adult obese patients attending academic Port-Foaud family health center.

\section{Study population}

A simple randomly selected sample of adults above 18 years' old with obesity attending to academic Port-Fouad family health center, Faculty of medicine at Suez Canal University were included. Patients with any of the following conditions were excluded from the study; 1 . Other chronic diseases (e.g., hypertension, chronic liver diseases, bronchial asthma, cancer, diabetes, hypothyroidism) 2. Complications of obesity as infertility. 3. Nearby bad social life event in the last 6 months as (operation, drug abuse, death of family member, breakup of beloved one, divorce). 4. Drug users (atypical antipsychotics, diabetes therapies, steroids hormone, anti-convulsions).

\section{Sample size}

It was planned to take a sample sufficient enough to demonstrate $20,6 \%{ }^{(14)}$ prevalence of major depressive disorder among the obese adults with $95 \%$ confidence interval. The sample size was calculated using a standard formula(15)

\section{Methods:}

Data were obtained from participants attending Port-Fouad family practice center from 9 a.m. to 2 p.m. from June to December 2018. All participants were subjected to the following 1- Structured questionnaire ${ }^{(16)}$ that contained 3 groups of questions:

\section{A. Socio-demographic data}

Age in years, residence, marital status, educational status, occupation and the loss of a close person during the past months.

\section{B. Economic data}

Monthly income and how sufficient (according to his/her perception).

C. Medical history

History of depression, hypertension, ischemic heart disease, diabetes mellitus, cerebrovascular stroke, urinary incontinence, tumor, other medical conditions (based on person's previous diagnosis and drugs) and his/her medication history and its duration. History of obesity: (duration, regimens, complications, drugs). (NB: Obesity is diagnosed when $\mathrm{BMI}$ is higher than 30 )

2-patient health questionnaire $9^{(17)}$

PHQ-9 is a widely used depression screening instrument in non-psychiatric settings.it can be scored using different methods including an algorithm based on diagnostic and statistical manual of mental disorders, fifth edition criteria and cut off based on summed item scores. This questionnaire is well validated. Scoring of depression: total score Depression severity was as follows: 0-4=None, 5-9=Mild, 1014=Moderate, 15-19=Moderately severe, 20-27=Severe ${ }^{(18)}$.

3-Nutritional history ${ }^{(19)}$

- Frequency of eating fruits, vegetables, meat, fish, legumes, dairy products, and fast foods

- Frequency of eating breakfast

- Eating in front of TV

- Number of main meals, number of snacks

- Size of meal

- When to stop feeding

- Frequency of drinking juices, tea and coffee

\section{Statistical analysis}

Data was analyzed by SPSS version 22, and EPI-Info statistical packages. The chisquare or Fisher exact tests as appropriate were used to compare categorical data 
and the student t-test and Analysis of Variance (ANOVA) was used to compare quantitative data. To estimate the independent association of each risk factor with depression, bivalent regression analysis was performed. $p<0.05$ are considered significant.

\begin{tabular}{|c|c|c|c|c|c|c|c|}
\hline \multicolumn{8}{|c|}{ Table 1: Sociodemographic data of obese patients according to their depression grades $(n=129)$} \\
\hline Variables & $\begin{array}{c}\text { none } \\
(n=35)\end{array}$ & $\begin{array}{c}\text { mild } \\
(n=34)\end{array}$ & $\begin{array}{c}\text { Moderate } \\
(\mathrm{n}=38)\end{array}$ & $\begin{array}{c}\text { Mod/Severe } \\
(n=18)\end{array}$ & $\begin{array}{c}\text { Severe } \\
(n=4)\end{array}$ & $\begin{array}{c}\text { test } \\
\text { value }\end{array}$ & $\begin{array}{c}\text { p- } \\
\text { value }\end{array}$ \\
\hline Age, mean $\pm S D$ & $\begin{array}{c}34.7 \pm \\
8.4\end{array}$ & $\begin{array}{c}34.9 \pm \\
9.5\end{array}$ & $32.2 \pm 8.1$ & $32.1 \pm 8.2$ & $38.1 \pm 10.8$ & 3.22 & $0.52^{\mathrm{a}}$ \\
\hline $\begin{array}{l}\text { Gender } \\
\text { Male } \\
\text { Female }\end{array}$ & $\begin{array}{l}20(57.1) \\
15(42.9)\end{array}$ & $\begin{array}{l}16(47.1) \\
18(52.9)\end{array}$ & $\begin{array}{l}15(39.5) \\
23(60.5)\end{array}$ & $\begin{array}{c}10(55.6) \\
8(44.4)\end{array}$ & $\begin{array}{c}0(0) \\
4(100)\end{array}$ & 6.08 & $0.18^{b}$ \\
\hline $\begin{array}{c}\text { Marital status } \\
\text { Single } \\
\text { Married } \\
\text { Divorced } \\
\end{array}$ & $\begin{array}{c}6(17.1) \\
28(80) \\
1(2.9) \\
\end{array}$ & $\begin{array}{c}6(17.6) \\
27(79.4) \\
1(2.9) \\
\end{array}$ & $\begin{array}{c}14(36.8) \\
24(63.2) \\
0(0) \\
\end{array}$ & $\begin{array}{l}6(33 \cdot 3) \\
9(50) \\
3(16.7\end{array}$ & $\begin{array}{l}1(25) \\
3(75) \\
0(0) \\
\end{array}$ & 12.9 & $0.06^{\mathrm{b}}$ \\
\hline $\begin{array}{c}\text { Educational level } \\
\text { Primary } \\
\text { Intermediate } \\
\text { High } \\
\text { University } \\
\end{array}$ & $\begin{array}{c}0(0) \\
1(2.9) \\
33(94.3) \\
1(2.9)\end{array}$ & $\begin{array}{c}0(0) \\
2(5 \cdot 9) \\
31(91.2) \\
1(2.9)\end{array}$ & $\begin{array}{c}0(0) \\
2(5 \cdot 3) \\
34(89.5) \\
2(5 \cdot 3) \\
\end{array}$ & $\begin{array}{c}1(5.6) \\
5(27.8) \\
12(66.7) \\
0(0) \\
\end{array}$ & $\begin{array}{c}0(0) \\
0(0) \\
4(100) \\
0(0)\end{array}$ & 16.1 & $0.11^{b}$ \\
\hline $\begin{array}{l}\text { Living conditions } \\
\text { Partner/siblings } \\
\text { Partner } \\
\text { Siblings } \\
\text { Relatives } \\
\text { Alone }\end{array}$ & $\begin{array}{c}23(65.7) \\
5(14 \cdot 3) \\
0(0) \\
7(20) \\
0(0)\end{array}$ & $\begin{array}{c}24(70.6) \\
4(11.8) \\
0(0) \\
6(17.6) \\
0(0) \\
\end{array}$ & $\begin{array}{c}20(33.3) \\
5(13.2) \\
0(0) \\
13(34.2) \\
0(0)\end{array}$ & $\begin{array}{l}6(33.3) \\
3(16.7) \\
1(5.6) \\
6(33.3) \\
2(11.1) \\
\end{array}$ & $\begin{array}{l}3(75) \\
0(0) \\
0(0) \\
1(25) \\
0(0)\end{array}$ & 20.1 & $0.17^{b}$ \\
\hline $\begin{array}{l}\text { Changes in social life last } \\
\text { year } \\
\text { No } \\
\text { Yes }\end{array}$ & $\begin{array}{c}34(97.1) \\
1(2.9) \\
\end{array}$ & $\begin{array}{c}33(97.1) \\
1(2.9) \\
\end{array}$ & $\begin{array}{c}37(97.4) \\
1(2.6)\end{array}$ & $\begin{array}{c}8(100) \\
0(0)\end{array}$ & $\begin{array}{c}4(100) \\
0(0)\end{array}$ & 1.74 & $0.99^{b}$ \\
\hline $\begin{array}{l}\text { Relative/ friend death in } \\
\text { the last year } \\
\text { Yes } \\
\text { No }\end{array}$ & $\begin{array}{c}0(0) \\
35(100)\end{array}$ & $\begin{array}{c}3(8.8) \\
31(91.2)\end{array}$ & $\begin{array}{c}3(7.9) \\
35(92.1)\end{array}$ & $\begin{array}{c}1(5.6) \\
17(94.4)\end{array}$ & $\begin{array}{c}0(0) \\
4(100)\end{array}$ & 3.79 & $0.39^{b}$ \\
\hline $\begin{array}{l}\text { Income } \\
\text { Sufficient } \\
\text { Not sufficient }\end{array}$ & $\begin{array}{c}2(5.7) \\
33(94.3)\end{array}$ & $\begin{array}{c}3(8.8) \\
31(91.2)\end{array}$ & $\begin{array}{c}4(10.5) \\
34(89.5)\end{array}$ & $\begin{array}{c}2(11.1) \\
16(88.9)\end{array}$ & $\begin{array}{c}0(0) \\
4(100)\end{array}$ & 1.10 & $0.91^{b}$ \\
\hline
\end{tabular}

$a=$ Kruskal Wallis test. ${ }^{b}=$ Fisher's Exact test. Statistical significance at $p<0.05$

\section{Results}

The sociodemographic data of studied population are shown in table 1 . The mean age of the patients in the different groups was comparable $(p=0.52)$. All the patients in severe depression were females. Moreover, half of the patients with moderately severe depression were married while $75 \%$ of the patients who were severely de- pressed were married. Most of the patients in moderately severe and severe groups were highly educated. Moreover, almost all patients with moderately severe and severe groups had insufficient income. Regarding clinical characteristics of the studied sample, only diastolic blood pressure was found to be significantly different based on different level of depression $(p=0.002)$. 


\begin{tabular}{|l|c|c|c|c|c|c|c|}
\hline \multicolumn{7}{|c|}{ Table 2: Association between grades of depression and different BMI categories (n=129) } \\
\hline Variables & $\begin{array}{c}\text { none } \\
(\mathrm{n}=35)\end{array}$ & $\begin{array}{c}\text { mild } \\
(\mathrm{n}=34)\end{array}$ & $\begin{array}{c}\text { Moderate } \\
(\mathrm{n}=38)\end{array}$ & $\begin{array}{c}\text { Mod. severe } \\
(\mathrm{n}=18)\end{array}$ & $\begin{array}{c}\text { Severe } \\
(\mathrm{n}=4)\end{array}$ & $\begin{array}{c}\text { test } \\
\text { value }\end{array}$ & $\mathrm{p}$ - \\
\hline Body mass index & $36.5 \pm 10.6$ & $35.4 \pm 4.3$ & $34.7 \pm 12.1$ & $35.2 \pm 4.4$ & $38.6 \pm 7.1$ & 5.34 & $0.25^{\mathrm{a}}$ \\
\hline BMI groups & & & & & & & \\
Overweight & $0(0)$ & $1(2.9)$ & $2(5.3)$ & $0(0)$ & $0(0)$ & 9.53 & $0.64^{\mathrm{b}}$ \\
Obesity grade I & $23(65.7)$ & $18(52.9)$ & $24(63.2)$ & $12(66.7)$ & $2(50)$ & & \\
Obesity grade II & $7(20)$ & $11(32.4)$ & $9(23.7)$ & $4(22.2)$ & $0(0)$ & & \\
Obesity grade III & $5(14.3)$ & $4(11.8)$ & $3(7.9)$ & $2(11.1)$ & $2(50)$ & & \\
\hline
\end{tabular}

On pairwise comparison, we found that patients with moderately severe depression had statistically significant higher diastolic blood pressure $(78.3 \pm 12.4)$ than that of patients with moderate depression (69.7 \pm 8.5) $(p=0.006)$. Most of the studied sample had grade I obesity (61\%). Moreover, one quarter of the patients was grade II obese and $13 \%$ of them were grade III obese. About $27 \%$ of the obese patients in our sample had no depression, whereas $14 \%$ had moderately severe depression and 3.1\% were severely depressed. No statistically significant relationship between grades of obesity and depression categories $(p=0.64)$ were shown (Table 2). About 53\% of the studied patients reported symptoms of loss of interest or pleasure (anhedonia) as well as having depressed mood only at some days (Table 3). Meanwhile, about $50 \%$ suffers insomnia or hypersomnia while $42 \%$ feel Fatigue or loss of energy at some of their days. Regarding the feeling of worthlessness or guilt, $34.1 \%$ had never experience that feeling, while $37.2 \%$ suffered that feeling only at some of their days. Meanwhile, $46.5 \%$ reported lack of the ability to think or concentrate and the same percentage had psychomotor agitation or retardation. $31.8 \%$ experienced significant weight loss, when not dieting/ weight gain/decrease or increase in appetite at some days, with equal percentage suffered these disturbances in weight/ appetite.

\begin{tabular}{|l|c|c|c|c|}
\hline \multicolumn{5}{|c|}{ Table 3. Symptoms of depression among obese patients (n=129) } \\
\hline Variables & $\begin{array}{c}\text { Never } \\
\mathrm{n}(\%)\end{array}$ & $\begin{array}{c}\text { Somedays } \\
\mathrm{n}(\%)\end{array}$ & $\begin{array}{c}\text { Most days } \\
\mathrm{n}(\%)\end{array}$ & $\begin{array}{c}\text { Every day } \\
\mathrm{n}(\%)\end{array}$ \\
\hline Loss of interest or pleasure & $38(29.5)$ & $68(52.7)$ & $17(13.2)$ & $6(4.7)$ \\
\hline Depressed mood & $25(19.4)$ & $70(54.3)$ & $30(23.3)$ & $4(3.1)$ \\
\hline Insomnia or hypersomnia & $28(21.7)$ & $64(49.6)$ & $30(23.3)$ & $7(5.4)$ \\
\hline Fatigue or loss of energy & $38(29.5)$ & $55(42.6)$ & $28(21.7)$ & $8(6.2)$ \\
\hline Feeling of worthlessness or inappropriate guilt & $44(34.1)$ & $48(37.2)$ & $27(20.9)$ & $10(7.8)$ \\
\hline Diminished ability to think or concentrate & $37(28.7)$ & $60(46.5)$ & $28(21.7)$ & $4(3.1)$ \\
\hline Psychomotor agitation or retardation & $35(27.1)$ & $59(45.7)$ & $32(24.8)$ & $3(2.3)$ \\
\hline $\begin{array}{l}\text { Significant weight loss when not dieting or } \\
\text { weight gain or decrease or increase in appetite }\end{array}$ & $34(26.4)$ & $41(31.8)$ & $41(31.8)$ & $13(10.1)$ \\
\hline Recurrent thought of death & $71(55)$ & $42(32.6)$ & $10(7.8)$ & $6(4.7)$ \\
\hline
\end{tabular}

Finally, more than half of the patients (55\%) never think about death. Table (4) shows eating frequency of different types of food of the studied sample. It was found that patients who consumed dairy products daily or at somedays were associated with less depression than those who never ate dairy product $(p=0.031)$. Otherwise, there was no significant association between different grades of depression and other food patterns. There was no statistically significant difference between patients 
with different depression scores in the number of main meals $(p=0.47)$ and number of snacks $(p=0.07)$. Moreover, half of the patients in moderately severe and severe depression eat large sized meals Table (5). By comparison between different depression groups showed that body dissatisfaction was significantly more associated with higher depression grade $(p=0.034)$. Otherwise, there was significant association between depression and any other medical variables Table (6). Multivariate linear regression analysis was used to assess predictors of depression among obese patients. R2 $=0.751$, where $75.1 \%$ of the variability of depression score among obese patients can be explained by this linear model. It was found that patients who were satisfied with their body had significantly 3.7 points lower in depression score than those who were not satisfied $(p=0.001)$ Table (7).

\section{Discussion}

Several lines of the literature suggested the association between obesity and the risk of depression. In their study to find out if obesity can cause Depression, $\mathrm{Ha}$ and colleagues used the Behavioral Risk Factor Surveillance System (BRFSS), which is an annual cross-sectional survey of the adult population (18 yrs or over). The BRFSS is a nationally representative sample based on a phone survey using both landlines and cell phones, and was established in 1984, covering 15 states. They found that BMI was found to have a positive effect on depression days and the percentage of depressed individuals in the population. Every 1-unit increase in the BMI increased depression by 0.159 days per month ${ }^{(14)}$. A community-based prospective study, in which participants were drawn from a statewide, community-based, Minnesota sample and were assessed via structured interview (depression) and study-measured height and weight, found that obesity that developed during late adolescence predicted the onset of depression $(\mathrm{OR}=5.89, \mathrm{Cl}=2.31-15.01)$ during early adulthood among females ${ }^{(15)}$. A university psychiatry department and student health center collaborated to develop the College Student Computer User Survey (CSCUS) to assess mental and physical health in a large sample of college students. A total of 2108 students completed the survey and they were classified by weight as normal, overweight or obese based on body mass index. Overweight and obesity were associated with significantly lower overall academic achievement, more depressive symptoms, and using diet pills for weight loss. Obese males had significantly higher rates of lifetime trichotillomania while overweight and obese females reported higher rates of panic disorder ${ }^{(20)}$. In current study $41.9 \%$ of obese participants were found to have mild depressive symptoms and $4.7 \%$ were severely depressed. These findings further support the results of previous studies. Lester et al. ${ }^{(25)}$ conducted a study on 70 consecutive obese outpatients seeking surgery to treat their obesity who were referred for a psychiatric evaluation prior to surgery. The results showed that $23 \%$ of this sample of obese patients had some suicidal risk and $32 \%$ had serious enough depression to require a psychiatric evaluation ${ }^{(21)}$. A previous study that involved 173 obese subjects was conducted to assess the prevalence of depression in subjects before starting a weight-reduction programme. Severe depression was diagnosed in 84 (48.5\%) subjects; mild depression was diagnosed in 65 (37.5\%) subjects, and 24 subjects did not have depression. They observed differences in BMI between subjects without depression and severe depression $(p<0.05)$ and between mild and severe depression ${ }^{(22,23)}$. 


\begin{tabular}{|c|c|c|c|c|c|c|c|}
\hline Variables & $\begin{array}{l}\text { none } \\
(n=35)\end{array}$ & $\begin{array}{c}\text { mild } \\
(n=34)\end{array}$ & $\begin{array}{c}\text { Moderate } \\
(n=38)\end{array}$ & $\begin{array}{c}\text { Mod. severe } \\
(n=18)\end{array}$ & $\begin{array}{l}\text { Severe } \\
(\mathrm{n}=4)\end{array}$ & test value & $\mathrm{p}$-value \\
\hline $\begin{array}{l}\text { Fruits and vegetables } \\
\text { Daily } \\
\text { Some days } \\
\text { Never }\end{array}$ & $\begin{array}{c}16(45.7) \\
14(40) \\
5(14.3)\end{array}$ & $\begin{array}{c}14(41.2) \\
17(50) \\
3(8.8)\end{array}$ & $\begin{array}{c}13(34.2) \\
22(57.9) \\
3(7.9)\end{array}$ & $\begin{array}{l}7(38.9) \\
9(50) \\
2(11.1)\end{array}$ & $\begin{array}{l}3(75) \\
0(0) \\
1(25)\end{array}$ & 7.16 & $0.50^{C}$ \\
\hline $\begin{array}{l}\text { Dairy products } \\
\text { Daily } \\
\text { Some days } \\
\text { Never } \\
\end{array}$ & $\begin{array}{c}18(51.4) \\
13(37.1) \\
4(11.4) \\
\end{array}$ & $\begin{array}{c}19(55.9) \\
14(41.2) \\
1(2.9) \\
\end{array}$ & $\begin{array}{c}8(21.1) \\
26(68.4) \\
4(10.5) \\
\end{array}$ & $\begin{array}{l}8(44.4) \\
8(44.4) \\
2(11.1) \\
\end{array}$ & $\begin{array}{l}2(50) \\
1(25) \\
1(25) \\
\end{array}$ & 15.11 & $0.031^{c}$ \\
\hline $\begin{array}{l}\text { Juices } \\
\text { Daily } \\
\text { Some days } \\
\text { Never }\end{array}$ & $\begin{array}{c}15(42.9) \\
13(37.1) \\
7(20) \\
\end{array}$ & $\begin{array}{l}12(35.3) \\
15(44.1) \\
7(20.6) \\
\end{array}$ & $\begin{array}{c}15(39.5) \\
19(50) \\
4(10.5) \\
\end{array}$ & $\begin{array}{l}8(44.4) \\
8(44.4) \\
2(11.1) \\
\end{array}$ & $\begin{array}{l}3(75) \\
1(25) \\
0(0) \\
\end{array}$ & 4.35 & $0.83^{c}$ \\
\hline $\begin{array}{l}\text { Tea and coffee } \\
\text { Daily } \\
\text { Some days } \\
\text { Never }\end{array}$ & $\begin{array}{c}29(82.9) \\
4(11.4) \\
2(5.7) \\
\end{array}$ & $\begin{array}{c}27(79.4) \\
7(20.6) \\
0(0)\end{array}$ & $\begin{array}{c}29(76.3) \\
7(18.4) \\
2(5.3) \\
\end{array}$ & $\begin{array}{c}13(72.2) \\
3(16.7) \\
2(5.3) \\
\end{array}$ & $\begin{array}{l}2(50) \\
2(50) \\
0(0)\end{array}$ & 7.59 & $0.42^{c}$ \\
\hline $\begin{array}{l}\text { Meat and fish } \\
\text { Daily } \\
\text { Some days } \\
\text { Never }\end{array}$ & $\begin{array}{c}20(57.1) \\
15(42.9) \\
0(0)\end{array}$ & $\begin{array}{c}20(58.8) \\
14(41.2) \\
0(0)\end{array}$ & $\begin{array}{c}16(42.1) \\
21(55.3) \\
1(2.6)\end{array}$ & $\begin{array}{c}12(66.7) \\
6(33.3) \\
0(0)\end{array}$ & $\begin{array}{l}2(50) \\
2(50) \\
0(0)\end{array}$ & 7.86 & $0.56^{c}$ \\
\hline $\begin{array}{l}\text { Legumes } \\
\text { Daily } \\
\text { Some days } \\
\text { Never }\end{array}$ & $\begin{array}{c}11(31.4) \\
20(57.1) \\
4(11.4)\end{array}$ & $\begin{array}{c}12(35.3) \\
21(61.8) \\
1(2.9)\end{array}$ & $\begin{array}{c}7(18.4) \\
30(78.9) \\
1(2.6)\end{array}$ & $\begin{array}{l}7(38.9) \\
9(50) \\
2(11.1)\end{array}$ & $\begin{array}{l}1(25) \\
2(75) \\
1(25)\end{array}$ & 10.46 & $0.18^{c}$ \\
\hline $\begin{array}{l}\text { Breakfast } \\
\text { Daily } \\
\text { Some days } \\
\text { Never } \\
\end{array}$ & $\begin{array}{l}28(80) \\
6(17.1) \\
1(2.9) \\
\end{array}$ & $\begin{array}{c}20(58.8) \\
13(38.2) \\
1(2.9) \\
\end{array}$ & $\begin{array}{c}30(78.9) \\
6(15.8) \\
2(5.3) \\
\end{array}$ & $\begin{array}{c}12(66.7) \\
6(33.3) \\
0(0) \\
\end{array}$ & $\begin{array}{l}3(75) \\
1(25) \\
0(0)\end{array}$ & 8.2 & $0.35^{c}$ \\
\hline $\begin{array}{l}\text { Fast foods } \\
\text { Daily } \\
\text { Some days } \\
\text { Never }\end{array}$ & $\begin{array}{c}7(20) \\
18(51.4) \\
10(28.6)\end{array}$ & $\begin{array}{c}7(20.6) \\
22(64.7) \\
5(14.7)\end{array}$ & $\begin{array}{c}8(21.1) \\
26(68.4) \\
4(10.5)\end{array}$ & $\begin{array}{l}7(38.9) \\
7(38.9) \\
4(22.2)\end{array}$ & $\begin{array}{c}0(0) \\
4(100) \\
0(0)\end{array}$ & 9.6 & $0.25^{c}$ \\
\hline $\begin{array}{l}\text { Eating in front of TV } \\
\text { Daily } \\
\text { Some days } \\
\text { Never }\end{array}$ & $\begin{array}{l}21(60) \\
8(22.9) \\
6(17.1)\end{array}$ & $\begin{array}{c}17(50) \\
12(35.3) \\
5(14.7)\end{array}$ & $\begin{array}{c}26(68.4) \\
7(18.4) \\
5(13.2)\end{array}$ & $\begin{array}{l}5(27.8) \\
7(38.9) \\
6(33.3)\end{array}$ & $\begin{array}{l}2(50) \\
2(50) \\
0(0)\end{array}$ & 11.21 & $0.16^{c}$ \\
\hline
\end{tabular}

${ }^{b}=$ Fisher's Exact test. Statistical significance at $p<.05$

In their study to assess the impact of weight loss on depression status in obese individuals, Deliopoulou et al., from Greece, included 100 consecutive females fulfilling criteria for balloon treatment. They were assessed for depression and divided into two groups (65 depressed, 35 non-depressed). During the treatment period, the depression status of the mildly, moderately, and severely depressed patients improved from 40, 32.3, and $27.7 \%$ to $20,7.7$, and $1.5 \%$, respectively, with $70.8 \%$ finally exhibiting no depression at all(24). A cross-sectional survey was conducted among primary care patients in 12 practices in Australia. Data were obtained from 3361 participants. The prevalence of depression was $24 \%$ (95\% confidence interval $[\mathrm{Cl}]=$ 
11.86 to 39.28$)$ among underweight participants, $11 \%(95 \% \mathrm{Cl}=8.5$ to 14.0$)$ among normal weight participants, $12 \%(95 \% \mathrm{Cl}=0.9$ to
15.2) among overweight participants, and $23 \%$ ( $95 \% \mathrm{Cl}=17.8$ to 29.0$)$ among obese participants $^{(25)}$.

\begin{tabular}{|c|c|c|c|c|c|c|c|}
\hline \multicolumn{8}{|c|}{ Table 5: Dietary habits characteristics of obese patients $(n=129)$} \\
\hline Variables & $\begin{array}{l}\text { none } \\
(n=35)\end{array}$ & $\begin{array}{l}\underset{(n=34)}{\text { mild }} \\
(n=3\end{array}$ & $\begin{array}{c}\text { Moderate } \\
(\mathrm{n}=38)\end{array}$ & $\begin{array}{l}\text { Mod. } \\
\text { severe } \\
(\mathrm{n}=18)\end{array}$ & $\begin{array}{l}\text { Severe } \\
(n=4)\end{array}$ & $\begin{array}{l}\text { test } \\
\text { value }\end{array}$ & $\begin{array}{c}\mathrm{p}- \\
\text { value }\end{array}$ \\
\hline $\begin{array}{l}\text { No. of main meals } \\
\text { mean } \pm \text { SD }\end{array}$ & $2.9 \pm 0.8$ & $3.1 \pm 0.37$ & $3.1 \pm 0.28$ & $2.8 \pm 0.51$ & $3.1 \pm 0.8$ & 3.5 & $0.47^{\mathrm{a}}$ \\
\hline $\begin{array}{c}\text { Size of meal } \\
\text { Small }\end{array}$ & $3(8.6)$ & $3(8.8)$ & $1(2.6)$ & $0(0)$ & $0(0)$ & & \\
\hline Medium & $23(65.7)$ & $25(73.5)$ & $26(68.4)$ & $9(50)$ & $2(50)$ & 8.36 & $0.34^{b}$ \\
\hline Large & $9(25.7)$ & $6(18$ & $11(28$ & $9(50)$ & $2(50)$ & & \\
\hline $\begin{array}{l}\text { No. of snakes, } \\
\text { mean } \pm \text { SD }\end{array}$ & $1.6 \pm 1.5$ & $1.3 \pm 1.4$ & $2.05 \pm 1.8$ & $2.5 \pm 1.88$ & $2.7 \pm 1.26$ & 8.7 & $0.07^{\mathrm{a}}$ \\
\hline When to stop feeding & & & & & & & \\
\hline At the middle of meal & $1(2.9)$ & $1(2.9)$ & $1(2.6)$ & $1(5.6)$ & $o(0)$ & & \\
\hline At feeling full stomach & $28(80)$ & $30(88.2)$ & $32(84.2)$ & $11(61.1)$ & $2(50)$ & 9.82 & $0.19^{b}$ \\
\hline $\begin{array}{l}\text { After feeling full } \\
\text { stomach }\end{array}$ & $6(17.6)$ & $3(8.8)$ & $5(13.2)$ & $6(33.3)$ & $2(50)$ & & \\
\hline
\end{tabular}

${ }^{a}=$ Kruskal Wallis test. ${ }^{b}=$ Fisher's Exact test. Statistical significance at $p<0.05$

The inconsistencies of percentages of depressed patients among obese subjects could be explained by the variability in the method of assessment of depression in each study. In the current study Diagnosis of major depressive episode according to
Phq 9. The aforementioned studies assessed depression depending on depression (D-score) of MMPI-2 11 (Lester et al., 2011), Beck's Depression Inventory $(\mathrm{BDI})^{(22,24)}$, and The Patient Health Questionnaire (PHQ-9) ${ }^{(25)}$ respectively.

\begin{tabular}{|c|c|c|c|c|c|c|c|}
\hline \multicolumn{8}{|c|}{ Table 6: Medical history of the obese patients $(n=129)$} \\
\hline Variables & $\begin{array}{c}\text { none } \\
(\mathrm{n}=35)\end{array}$ & $\begin{array}{c}\text { mild } \\
(\mathrm{n}=34)\end{array}$ & $\begin{array}{c}\text { Moderate } \\
(n=38)\end{array}$ & $\begin{array}{c}\text { Mod. severe } \\
(n=18)\end{array}$ & $\begin{array}{c}\text { Severe } \\
(\mathrm{n}=4)\end{array}$ & $\begin{array}{c}\text { test } \\
\text { value }\end{array}$ & p-value \\
\hline $\begin{array}{l}\text { Duration of obesity, } \\
\text { mean } \pm \text { SD }\end{array}$ & $8.5 \pm 5.3$ & $7.3 \pm 4.7$ & $6.3 \pm 4.5$ & $9.4 \pm 6.2$ & $9.0 \pm 8.2$ & 4.8 & $0.31^{\mathrm{a}}$ \\
\hline \multicolumn{8}{|l|}{ Trials for diet control } \\
\hline No & $14(41.2)$ & $13(38.2)$ & $13(34.2)$ & $4(22.2)$ & $2(50)$ & \multirow{2}{*}{2.5} & \multirow{2}{*}{$0.67^{\mathrm{b}}$} \\
\hline Yes & $21(58.9)$ & $21(61.8)$ & $25(65.8)$ & $14(77.8)$ & $2(50)$ & & \\
\hline $\begin{array}{l}\text { No. of trials for diet control, } \\
\text { mean } \pm \text { SD }\end{array}$ & $2.0 \pm 2.68$ & $1.85 \pm 2.06$ & $1.6 \pm 1.7$ & $2.6 \pm 2.5$ & $3.7 \pm 5.2$ & 2.3 & $0.67^{a}$ \\
\hline \multicolumn{8}{|l|}{ Body satisfaction } \\
\hline No & $21(60)$ & $25(73.5)$ & $31(81.6)$ & $17(94.4)$ & $4(100)$ & \multirow{2}{*}{9.8} & \multirow{2}{*}{$0.034^{b}$} \\
\hline Yes & $15(41.3)$ & $9(26.5)$ & $7(18.4)$ & $1(5.6)$ & $0(0)$ & & \\
\hline \multicolumn{8}{|l|}{ History of depression } \\
\hline No & $32(94.1)$ & $34(100)$ & $35(92.1)$ & $15(83.3)$ & $4(100)$ & \multirow{2}{*}{5.7} & \multirow{2}{*}{$0.16^{b}$} \\
\hline Yes & $3(5.9)$ & $0(0)$ & $3(7.9)$ & $3(16.7)$ & $0(0)$ & & \\
\hline \multicolumn{8}{|l|}{ Chronic disease } \\
\hline Absent & $35(97.1)$ & $34(100)$ & $38(100)$ & $17(94.4)$ & $4(100)$ & \multirow[b]{2}{*}{4.4} & \multirow{2}{*}{$0.37^{b}$} \\
\hline Present & $1(2.9)$ & $0(0)$ & $0(0)$ & $1(5.6)$ & $0(0)$ & & \\
\hline
\end{tabular}

$a=$ Kruskal Wallis test. ${ }^{b}=$ Fisher's Exact test. Statistical significance at $p<0.05$ 
In the current study, by comparison between the depressed and non-depressed participants, depressed patients were significantly less satisfied with their body shape $(p=0.008)$. Furthermore, by logistic regression analysis to assess predictors of depression among obese patients, the best-fitting predictor of depression was body satisfaction. This was in accordance with the findings of an observational study which assessed body attitude, body satisfaction and body awareness in a clinical group of depressed patients and the influence of treatment. The study was performed at the Department of Mood and Anxiety Disorders, University Center for Psychiatry (UCP), University Medical Center Groningen (UMCG), and a tertiary academic centre. During a period of 18 months all patients starting the three months' inpatient treatment or day treatment, patients scored significantly lower than a healthy comparison sample on body attitude and body satisfaction. After treatment, depression scores decreased, scores for body attitude and body satisfaction in creased. Medium pre-treatment and strong post-treatment associations were found between depression severity and body attitude and between depression severity and body satisfaction ${ }^{(26)}$. A number of longitudinal studies have found that body dissatisfaction in adolescence is associated with a heightened risk for subsequent depressive symptoms $(27,28)$. Salafia and Gondoli have recently conducted a study in which the data were collected as part of a larger project investigating parenting and child outcomes during the transition to adolescence ${ }^{(29)}$. Initial contact letters were distributed by primary schools in a medium-sized, Midwestern city or by direct mailings to parents of children in fourth grade. They documented from data of 85 mother-girl dyads that body dissatisfaction in early adolescence may predispose girls to later depressive symptoms as well as bulimic symptoms and dieting behaviors. Others stated that body dissatisfaction prospectively predicted the risk of suicidal ideation in early-adolescent girls and mid-adolescent boys(30).

\begin{tabular}{|c|c|c|c|c|c|}
\hline \multirow{2}{*}{ Predictors } & \multicolumn{2}{|c|}{ Unstandardized Coefficients } & \multirow{2}{*}{$\begin{array}{c}\text { Standardized } \\
\text { Coefficients } \\
\text { Beta }\end{array}$} & \multirow{2}{*}{$(95 \% \mathrm{Cl})$} & \multirow{2}{*}{$P$ value } \\
\hline & B & Std. Error & & & \\
\hline (Constant) & 8.433 & 4.135 & & & $0.044^{*}$ \\
\hline \multicolumn{6}{|l|}{ Dairy product } \\
\hline Never & \multicolumn{2}{|c|}{ Reference } & & & \\
\hline Somedays & -0.455 & 1.715 & -0.041 & $(-3.85-2.939)$ & 0.791 \\
\hline Daily & -1.734 & 1.722 & -0.153 & $(-0.5 .141-1.674)$ & 0.316 \\
\hline Diastolic BP & 0.034 & 0.050 & 0.059 & $(-0.065-0.132)$ & 0.500 \\
\hline \multicolumn{6}{|l|}{ Body satisfaction } \\
\hline Not satisfied & \multicolumn{2}{|c|}{ Reference } & & & \\
\hline Satisfied & -3.688 & 1.118 & -0.283 & $(-5.902--1.474)$ & $0.001 *$ \\
\hline
\end{tabular}

Data were obtained from Korea Youth Panel Survey data sets for early adolescents ( 1380 boys and 1209 girls, Time 1 mean age 10 years) and mid-adolescents
(1429 boys and 1437 girls, Time 1 mean age 15 years) and from follow-up surveys of the same individuals after 2 years. Santos et al. conducted a study on Two hundred and 
forty one high school students (115 males and 126 females) from a southwestern high school and found that body dissatisfaction and low self-esteem and low social support were all found to be significantly related to depressive symptoms $(\mathrm{p}<0.01)^{(31)}$. In current study, there was not any statistically significant difference between depressed and non-depressed participants regarding age according to $\mathrm{WHO}$, age was from 25 to 45 as youth. Also there was not statically significant difference in gender as $52.5 \%$ of our sample was males and $47.5 \%$ were females. There was not statically significant difference in marital status, educational level, living conditions, or changes in social life last year. In contrast, almost all community epidemiological studies of the previous literature find that gender, age, and marital status are associated with depression. Women typically have a two-fold increased risk of major depression compared to men, individuals who are separated or divorced have significantly higher rates of major depression than the currently married, and prevalence of major depression generally goes down with age ${ }^{(32-34)}$. This evidence, however, comes primarily from studies conducted in Western countries. The sparse data available from low-middle income countries suggest that the age pattern might either be non-monotonic or reversed compared to other countries, with depression increasing with age ${ }^{(35)}$. In five low-middle income countries, there was no significant association between age and depression(33). Other socioeconomic factors have less consistent relationships with major depression in different countries(32). Gender difference regarding depression was however, frequently mentioned in the literature as an important factor. Several studies reported that females have an increased risk regarding depression $(36,37)$. Body dissatisfaction may play as a contrib- utor to the gender differences in depression. Body dissatisfaction not only poses a risk to adolescent wellbeing but is also a gendered preoccupation, given that body image concerns appear to be both more frequent and motivationally significant in females than in male. As a result, body dissatisfaction can be expected to be involved in the gender imbalance in depressive symptoms ${ }^{(37)}$. The percentage of depression was higher in females in our sample; however, it was insignificant. Our small sample size could have caused this hidden significance .In current study, comparison of dietary habits variables between the two groups showed that depressed patients had significantly a greater number of snakes ( $2.25 \pm 1.83$ times) than those with no depression $(p=0.011)$. That was consistent with the previous literature as in several prospective partly large studies an unhealthy western dietary pattern was associated with an increased prevalence of depression. Moreover, the consumption of sweetened beverage, refined food, fried food, processed meat, refined grain, and high fat intake, biscuit snacking and pastries have been shown to be associated with an increased risk of depression in longitudinal studies $(38,39)$. In current study, frequency of eating dairy products was significantly different between depressed and non-depressed patients $(p=0.027)$ with a protective effect of the daily intake of dairy products. Similarly, a healthy whole food pattern was associated with a $26 \%$ lower risk of elevated depressive symptoms in middle-aged British subjects. ${ }^{40} \mathrm{~A}$ cross-sectional study among Iranian adults showed that a lacto-vegetarian dietary pattern that contained high intakes of fruits, vegetables and low-fat dairy products was protectively associated with anxiety ${ }^{(41)}$. In current study, no significant difference between depressed and non-depressed participants 
regarding number or size of meals. However, A multivariable logistic regression analysis of dietary habits in a recent study in south Korea showed that depression correlated inversely with eating out $(\geq 1$ time/day Vs $<1$ time/month) among men [odds ratio $(O R)=0.23,95 \%$ confidence interval $(\mathrm{Cl})$ : $0.10-0.55]$ and women $(\mathrm{OR}=$ $0.14,95 \% \mathrm{Cl}: 0.05-0.35)$ and positively with a lower number of daily meals ( $<3 \mathrm{Vs} \geq 3$ ) among women $(\mathrm{OR}=1.45$, 95\% Cl: $1.01-$ $2.11)^{(42)}$. Different cultural background of this setting (South Korea) may be a possible explanation of this rather inconsistency.

\section{Conclusion}

Depression often accompanies obesity. The level of depression is increased in morbidly obese persons in comparison to moderately obese patients. Dietary patterns have a great effect on the psychological status and the depressive symptoms. Therefore, it is recommended that health professionals should always explore the presence of depression and suicidality in obese patients to correct their obesity. In obese persons the important issue in a weight-reduction management seems to be psychotherapy and, in some cases, pharmacological treatment of depression. It also seems that psychotherapy may be an important factor of preventing obesity and depression, especially in people prone to stressful situations. Thus, obese people should be seen as potential psychiatric patients and evaluated before obesity treatment.

\section{References}

1. Douglas PK, Douglas DB, Harrigan DC, et al. Preparing for pandemic influenza and its aftermath: mental health issues considered. Int J Emerg Ment Health., 2009;11(3), 137.
2. Overton RC. A comparison of fixed-effects and mixed (random-effects) models for meta-analysis tests of moderator variable effects. Psychological Methods. 2008; 3:354-379.

3. WHO Global InfoBase Team. Comparison BMI levels between countries.2016

4. Fawzy MS., Alhadramy O, Hussein MH, et al. Functional and structural impact of ATP-binding cassette transporter A1 R219K and I883M gene polymorphisms in obese children and adolescents. Molecular diagnosis \& therapy, 2015; 19(4), 221-234.

5. Musaiger A, and Al-mannai M. Association between exposure to media and body weight concern among female university students in five Arab countries: a preliminary cross-cultural study. J Biosocial Sci .2013; 46(2): 240-247.

6. Muhlig Y, Antel J, Focker M, et al. Are bidirectional associations of obesity and depression already apparent in childhood and adolescence as based on high-quality studies? A systematic review. Obes Rev. 2016; 17:235-249.

7. Doi SA, Barendregt JJ, Mozurkewich EL. Meta-analysis of heterogeneous clinical trials: an empirical example. Contemp Clin Trials. 2011; 32:288-298.

8. Liem ET, Sauer PJ, Oldehinkel AJ, et al. Association between depressive symptoms in childhood and adolescence and overweight in later life: review of the recent literature. Arch Pediatr Adolesc Med. 2008; 162:981-988.

9. Khader Y, Batieha A, Ajlouni H. Obesity in Jordan: prevalence, associated factors, comorbidities, and change in prevalence over ten years. Metab Syndr Relat Disord. 2008; 6(2): 113-120.

10. Brockwell SE, and Gordon IR. A comparison of statistical methods for meta-analysis. Stat Med. 2006; 20:825840.

11. Puhl RM, and Heuer CA. The stigma of obesity: a review and update. Obesity (Silver Spring). 2009; 17:941-964.

12. von Elm E, Altman DG, Egger $M$, et al. The Strengthening the Reporting of 
Observational Studies in Epidemiology (STROBE) Statement: guidelines for reporting observational studies. Int J Surg. 2014; 12:1495-1499.

13. Blaine B. Does depression cause obesity? A meta-analysis of longitudinal studies of depression and weight control. J Health Psychol. 2008; 13:11901197.

14. Hasin, D. S., Sarvet, A. L., Meyers, J. L., Saha, T. D., Ruan, W. J., Stohl, M., \& Grant, B. F. Epidemiology of adult DSM5 major depressive disorder and its specifiers in the United States. JAMA psychiatry, 2018; 75(4), 336-346.

15. Triola M. Elementary statistics. Addison-Wsley product, pp.2004; 317- 318.

16. Skinner AC, and Skelton JA. Prevalence and trends in obesity and severe obesity among adults in the United States, 1999-2012. JAMA Pediatr. 2014; 168:561-566.

17. Julio C, and Sergio L."DSM-5 criteria and depression severity implications clinical practice". 2018; 9:450.

18. Jerry L, Halverson MD, David B. DSM-5 criteria for diagnosis of major depressive disorder. 2020 at: https://www.medscape.com/answers/286759-14692/what-are-thedsm-5-criteria-for-diagnosis-of-majordepressive-disorder-clinical-depression

19. Sarma H, Saquib N, Hasan M. Determinants of overweight or obesity among ever-married adult women in Bangladesh. BMC Obesity.2016; 3: 13.

20. Ha H, Han C, Kim B. Can obesity cause depression? A pseudo-panel analysis. J Prev Med Public Health. 2017; 50(4):262-267.

21. Goadsby PJ, Kurth T, Pressman A. HHS Public Access. 2016; 35(14):1252-1260.

22. Wimmelmann CL, Odlaug BL, Mortensen EL. Prevalence and correlates of being overweight or obese in college. Psychiatry Res. 2015; 227(1):58-64.

23. Olszanecka-Glinianowicz M, ZahorskaMarkiewicz B, Kocełak P. Depression in obese persons before starting complex group weight-reduction programme. Int J Soc Psychiatry. 2009; 55(5):407-413

24. Deliopoulou K, Konsta A, Penna S, et al. The impact of weight loss on depression status in obese individuals subjected to intragastric balloon treatment. Obes Surg. 2013;23(5):669-675.

25. Lester D, Pompili M, lliceto P, et al. Depression and Suicidality in Obese $\mathrm{Pa}$ tients.PsycholRep.2011;108(2):367-368.

26. Zametkin AJ, Zoon CK, Klein HW, et al. Psychiatric aspects of child and adolescent obesity: a review of the past 10 years. J Am Acad Child Adolesc Psychiatry (Review). 2009; 43 (2): 134-50.

27. Nikolic M. Prevalence of comorbid depression and obesity in general practice. Br J Gen Pract. 2015; 65(638):451.1451.

28. Scheffers $M$, van Duijn MAJ, Beldman $M$, et al. Body attitude, body satisfaction and body awareness in a clinical group of depressed patients: An observational study on the associations with depression severity and the influence of treatment. J Affect Disord. 2019; 242:22-28.

29. Blodgett Salafia EH, Gondoli DM. A 4Year Longitudinal Investigation of the Processes by Which Parents and Peers Influence the Development of Early Adolescent Girls' Bulimic Symptoms. J Early Adolesc. 2011; 31(3):390-414.

30. Kim DS, and Kim HS. Body-Image Dissatisfaction as a Predictor of Suicidal Ideation Among Korean Boys and Girls in Different Stages of Adolescence: A Two-Year Longitudinal Study. J Adolesc Heal. 2009; 45(1):47-54.

31. Santos, M., Richards, C. S., \& Bleckley, M. K. Comorbidity between depression and disordered eating in adolescents. Eating Behaviors, 2007;8(4):440-449.

32. Johnson F, and Wardle J. Dietary Restraint, Body Dissatisfaction, and Psychological Distress: A Prospective Analysis. J Abnorm Psychol. 2005; 114(1):119125. 
33. Paxton SJ, Neumark-Sztainer D, Hannan PJ, et al. Body Dissatisfaction Prospectively Predicts Depressive Mood and Low Self-Esteem in Adolescent Girls and Boys. J Clin Child Adolesc Psychol. 2006; 35(4):539-549.

34. Kessler RC, Birnbaum HG, Shahly V. Age differences in the prevalence and co-morbidity of DSM-IV major depressive episodes: results from the WHO World Mental Health Survey Initiative. Depress Anxiety. 2014; 27(4):351-364

35. Van de Velde S, Bracke P, Levecque K. Gender differences in depression in 23 European countries. Cross-national variation in the gender gap in depression. Soc Sci Med. 2010; 71(2):305-313

36. . Andrade L, Caraveo-Anduaga JJ, Berglund $P$. The epidemiology of major depressive episodes: results from the International Consortium of Psychiatric Epidemiology (ICPE) Surveys. Int $J$ Methods Psychiatr Res. 2003;12(1):3-21.

37. Bromet EJ, Gluzman SF, Paniotto VI. Epidemiology of psychiatric and alcohol disorders in Ukraine. Soc Psychiatry Psychiatr Epidemiol. 2010;40(9):681690.

38. Faravelli C, Alessandra Scarpato M, et al. Gender differences in depression and anxiety: The role of age. Psychiatry Res. 2013; 210(3):1301-1303.
39. Ferreiro F, Seoane G, Senra C. Toward understanding the role of body dissatisfaction in the gender differences in depressive symptoms and disordered eating: A longitudinal study during adolescence. J Adolesc. 2014; 37(1):73-84.

40. Ciarambino T, Castellino P, Paolisso G. Long term effects of low protein diet on depressive symptoms and quality of life in elderly Type 2 diabetic patients. Clin Nephrol. 2012;78(08):122-128.

41. Ruusunen A, Lehto SM, Mursu J. Dietary patterns are associated with the prevalence of elevated depressive symptoms and the risk of getting a hospital discharge diagnosis of depression in middle-aged or older Finnish men. J Affect Disord. 2014; 159:1-6.

42. Akbaraly TN, Brunner EJ, Ferrie JE, et al. Dietary pattern and depressive symptoms in middle age. $\mathrm{Br} J$ Psychiatry. 2009;195(05):408-413.

43. Hosseinzadeh $M$, Vafa $M$, Esmaillzadeh A. Empirically derived dietary patterns in relation to psychological disorders. Public Health Nutr. 2016; 19(02):204

44. Seo Y, and Je Y. A comparative study of dietary habits and nutritional intakes among Korean adults according to current depression status. Asia-Pacific Psychiatry. 2018; 10(3):1-9. 